\title{
SOCIAL RETURN ON INVESTMENT
}

SROI adalah suatu pengukuran untuk memudahkan sebuah organisasi tertentu memahami dan mengelola nilai social, lingkungan serta ekonomi yang ada. SROI biasanya digunakan untuk mengidentifikasi nilai apa yang memiliki perbedaan dan dampak antara budaya dengan masyarakat di tempat tersebut. SROI menegaskan bahwa nilai sosial suatu kegiatan tidak terpaku pada biaya yang dihabiskan.

Contoh penerapan SROI di Surabaya adalah Surabaya Green dan Clean Festival.

Berikut merupakan beberapa contoh artikel yang menggunakan analisis SROI:

1. Wetlands, Flood Control and Ecosystem Services in the Smith Creek Drainage Basin: A Case Study in Saskatchewan, Canada (https://www.sciencedirect.com/science/article/abs/pii/S0921800917309084)

2. Riparian wetland conservation: A case study of phosphorous and social return on investment in the Black River watershed (https://www.sciencedirect.com/science/article/abs/pii/S2212041616303904)

3. Social Return On Investment (SROI): Problems, solutions ... and is SROI a good investment?

(https://www.sciencedirect.com/science/article/abs/pii/S014971891630249X)

4. The social value of the arts for care home residents in England: A Social Return on Investment analysis of the Imagine Arts programme (https://www.sciencedirect.com/science/article/abs/pii/S0378512218308375)

5. Evaluating societal outcomes of orthognathic surgery: an innovative application of the Social Return on Investment methodology to patients after orthognathic treatment (https://www.sciencedirect.com/science/article/abs/pii/S0266435619300014)

Kelebihan SROI sendiri dapat mengukur dan menghitung perubahan dalam konsep nilai yang lebih luas. Di samping itu, SROI mengurangi ketidaksetaraan dan juga dapat mengurangi degradasi lingkungan. SROI juga dapat digunakan untuk meningkatkan kesejahteraan masyarakat atau pihak terlibat dengan menggabungkan dana dan manfaat dari aspek sosial, lingkungan, dan ekonomi.

Bagaimana pun juga, SROI juga memiliki kelebihan seperti dibutuhkannya dukungan penerapan SROI harus berasal dari seluruh pihak yang terlibat sehingga akan membutuhkan 
waktu yang lebih lama untuk perkembangannya. Selain itu, adanya tingkat subjektivitas akibat wajibnya penerapan kebijakan tiap pihak yang mendukung/terlibat ketika memperhitungkan dan mengevaluasi efek SROI juga menjadi salah satu kendala dari penerapan SROI.

Sumber:

https://blog.amartha.com/social-return-on-investment/

https://socialinvestment.id/portfolio-items/sroi/

https://majalahcsr.id/pengantar-sroi-social-return-of-investment/

http://elib.ubaya.ac.id/lib/ebook-jurnal/ 